\title{
VENTRE COLONIZADO: INTERSECÇÕES ENTRE A PINTURA ORIENTALISTA E AS DANÇAS ÁRABES
}

\author{
Nina Ingrid Caputo Paschoal (PUC-SP)
}

"Ventre colonizado: intersecções entre a pintura orientalista e a dança árabe", pesquisa de mestrado em andamento com previsão de conclusão em dezembro de 2018 , se iniciou a partir de uma busca aprofundada sobre as origens das danças árabes, hoje mais conhecida como Dança do Ventre, e o impacto que as incursões ocidentais nos países árabes podem ter em relação a estas manifestações culturais. Dentro dos estudos da história das danças, as modalidades árabes e a Dança do Ventre sofrem com muitas lacunas, tornando dificultosa qualquer tentativa de situá-las tanto em suas práticas originárias quanto no seu processo de chegada ao hemisfério ocidental. As fontes levantadas, escolhidas e analisadas são parte da cultura visual e imagética: pinturas do século XIX que retratam cenas de danças realizadas por mulheres árabes. Esta pesquisa busca o aprofundamento em uma arte, a dança, através de outra, a pintura. A pesquisa "Ventre colonizado" busca contribuir dentro da área de estudos culturais ao utilizar de bibliografia fundada neste conceito. Esta natureza discursiva traz à tona a revisão de saberes hegemônicos, ou seja, tópicos ensinados por séculos a fio e "aceitos" por nós como verdade consagrada que excluiu diversos sujeitos do direito de contar sua própria história. Muitos destes ensinamentos se formaram enquanto parte do grande quebra-cabeça formado pela intenção de difundir um discurso que atendesse a propósitos diretamente relacionados ao processo colonizador e imperialista que se estendeu pela Europa durante os séculos XVIII, XIV e mesmo XX. O estudo, portanto, tem sua justificativa pautada nesta necessidade de reconhecermos tais propósitos como manipuladores de sujeitos e de crenças e criador de estereótipos e imagens pré-concebidas que, em grande parte das vezes, anula a identidade dos povos as quais se referem, e faz perpetuar uma mentalidade de preconceito e/ou exotização e erotização das referidas culturas.

Palavras-chave: dança; discurso; orientalismo. 